\title{
IMMUNOMODULATION AND STRENGTHENING OF SERUM MINERAL PROFILE BY DIETARY SUPPLEMENTATION OF PROTEIN, PROBIOTICS AND VITAMINS (C AND E) IN MOLTED LAYER BREEDERS
}

\author{
Aisha Mahmood ${ }^{1, *}$, Tanweer Khaliq1, Sajjad-ur-Rahman², Zia-ur-Rahman', Junaid Ali Khan', \\ Humaira Muzaffar ${ }^{1}$, Asghar Ali ${ }^{1}$ and Arslan Iftikhar ${ }^{3}$
}

\author{
${ }^{1}$ Institute of Pharmacy, Physiology and Pharmacology, University of Agriculture, Faisalabad, Pakistan; \\ ${ }^{2}$ Institute of Microbiology, University of Agriculture, Faisalabad, Pakistan; ${ }^{3}$ Department of Physiology, Government \\ College University, Faisalabad, Pakistan. \\ *Corresponding author's e-mail: ishavet88@yahoo.com
}

\begin{abstract}
This study was executed to test the effect of low crude protein (12\% CP), probiotics (Protexin $\left.{ }^{\circledR}\right)$, vitamins $(\mathrm{C}$ and E) and combination of these treatments on serum mineral profile, cell mediated and humoral immunity of molted White Leghorn breeder males. Birds of 59 weeks age $(n=270)$ were maintained at animal house of Faculty of Veterinary Science, University of Agriculture, Faisalabad, for this study. Normal breeder diet containing crude protein (CP) $16 \%$ (140 g/bird/day) was provided with fresh drinking water (ad libitum) and daily lighting schedule of 16 hours was fixed. After one week acclimatization, all the birds were forced molted by dietary $\mathrm{ZnO}(3 \mathrm{~g} / \mathrm{Kg}$ diet) until desired body weight reduction. These birds were divided into six groups (45 birds/group), post molting. Group A served as a control (normal diet). Other Groups were supplemented with diet containing vitamin C $(500 \mathrm{mg} / \mathrm{Kg})$, vitamin E $(90 \mathrm{mg} / \mathrm{Kg})$, probiotics $(0.05 \mathrm{~g} / \mathrm{Kg}), 12 \% \mathrm{CP}$ and a combination of the aforementioned supplementations, respectively. Serum samples were collected for five consecutive weeks at one week interval after the start of semen production. Significant $(\mathrm{P} \leq 0.05)$ increase in serum concentrations of sodium, magnesium and calcium were found in vitamin E supplemented group. Macrophage engulfment percentage was also higher in both opsonized and unopsonized conditions $(60$ and $90 \mathrm{~min}$ ) in vitamin E supplemented group. Moreover, serum antibody titers against ND (heamagglutination inhibition) and IB (indirect ELISA) were improved. In conclusion, vitamin E may be the best option for improving health and immunity against these diseases, during post molt period.
\end{abstract}

Keywords: Probiotics, cell mediated immunity, humoral immunity, macrophage engulfment percentage, opsonized, unopsonized.

\section{INTRODUCTION}

Molting is a natural phenomenon in birds during which periodic replacement and shedding of feathers occur. However, retired birds are commonly molted through forced molting. This technique is an economical and important management tool, used extensively in poultry industry to rejuvenate internal organs of birds for second and third cycle of production with an intention to improve their production efficiency. Molting is done by various methods i.e. feed withdrawal, photoperiod reduction, low aluminum, iodine diet (Khan et al., 2011), low energy, protein, calcium, sodium feed and high dietary zinc, (Wu et al., 2000). Among forced molting, $\mathrm{Zn}$ induced molting is considered to be superior (Khan et al., 2011), because of strengthening of acquired immune response in hen during second cycle of production (Sandhu et al., 2006) and more IgG and IgM production (Sandhu et al., 2007).

Besides molting, there are other factors such as restriction of dietary protein, supplementation of probiotics (Li et al., 2014) and vitamins, which are also known to affect the subsequent performance of molted birds (Khan et al., 2014). Crude protein (CP) is important for growth, reproductive performance and development of gastrointestinal tract and villus area. However, lower protein level improves beneficial intestinal microflora. Probiotics ('for life') are live microbial poultry feed supplements which improve microbial balance in intestine. Dietary inclusion of probiotics has also shown to improve immune response in chicks (Khan et al., 2013). A diet supplemented with probiotic or symbiotic or rich in protein enhances immunity of the body in molted hens (Anwar et al., 2015). Vitamins (C and E) play important role in improving health status of molted White Leghorn breeder males (Iftikhar et al., 2015). Vitamin E showed increased immunity in chickens against various diseases like infectious bursal disease (IBD), E.coli infection, coccidiosis and Newcastle disease (Akbari et al., 2008). It also plays important role in modulating serum mineral profile, as $\mathrm{Mg}$ level increases by the supplementation of vitamin E (Khan et al., 2013). Vitamin $C$ plays an important role in the metabolism of minerals and amino acids. Vitamin C supplementation has been reported to improve IBD induced 
immunosuppression, along with cellular and humoral immunity (Wu et al., 2000). Serum concentration of Ca, P, K, $\mathrm{Fe}$ and $\mathrm{Zn}$ was found to increase in quails with supplementation of ascorbic acid in their diet (Sahin et al., 2001).

Practices like protein restriction, provision of probiotics, vit. $\mathrm{C}$ and $\mathrm{E}$ have been used in broilers, layers and broiler breeders for determination of cell mediated immunity, humoral immunity and serum mineral profile, however, information regarding the use of these supplements in male layer breeders is scanty. This study was therefore, planned to investigate the impact of protein, probiotics vit. $\mathrm{C}$ and $\mathrm{E}$ on immunological (cell mediated immunity, humoral immunity) and health profile of retired male layer breeders after molting.

\section{MATERIALS AND METHODS}

Experimental design: Two hundred seventy, White Leghorn breeder males (age=59 weeks) were procured from a commercial poultry breeder farm. The birds were acclimatized for one week and fed layer breeder diet (140 g/bird/day) having $16 \% \mathrm{CP}$. Fresh drinking water was available ad libitum and daily lighting schedule of 16 hours was fixed. Birds were immunized at $60^{\text {th }}$ week against ND and IB (MSD-Intervet $\left.{ }^{\circledR}\right)$ through drinking water. At the start of $2^{\text {nd }}$ week, all the birds were subjected to forced molting process through feeding zinc oxide ( $3 \mathrm{~g} / \mathrm{kg}$ feed) and gradually decreasing day light from 16 to 12 hours. Dietary addition of $\mathrm{ZnO}$ was continued till the body weight of the birds was reduced by $20-25 \%$. After completion of molting, the birds were randomly divided into six groups having 45 birds in each group. First group served as control and was kept on normal layer breeder diet. Whereas, the birds in remaining groups were fed diet supplemented with vitamin $\mathrm{C}(500 \mathrm{mg} / \mathrm{Kg})$, vitamin E (90 mg/Kg), probiotics (Protexin ${ }^{\circledR}$; @ $0.05 \mathrm{~g} / \mathrm{Kg}$ of feed), protein (12\%) and a combination of the aforementioned supplementations, respectively.

Sample collection and determination of mineral profile: Serum samples from birds were collected after one week of first semen ejaculate and continued for the next five weeks. Collected serum samples from 6 birds/group were analysed for the determination of macro and micro minerals concentration. Serum samples (1 $\mathrm{ml}$ each) were subjected to wet digestion as described by Rahman and Akhtar (1993). The concentration of calcium $(\lambda=422.7 \mathrm{~nm})$, magnesium $(\lambda=285.2 \mathrm{~nm})$, copper $(\lambda=324.8 \mathrm{~nm})$, zinc $(\lambda=213.9 \mathrm{~nm})$, manganese $(\lambda=279.6 \mathrm{~nm})$ and iron $(\lambda=248.3 \mathrm{~nm})$ was determined by atomic absorption spectrometer (Hitachi Polarized Zeeman, Japan). Concentrations of $\mathrm{Na}$ and $\mathrm{K}$ were determined by flame photometer by subjecting all the samples to wet digestion.

Macrophage engulfment assay

Harvesting abdominal macrophage cells: The method described by Qureshi et al. (1986) was used to collect the abdominal exudate macrophages. Briefly, 3\% pre swollen Sephadex G-50 ${ }^{\circledR}$ (Sigma) suspension was injected I/P @ 10 $\mathrm{mL} / \mathrm{kg}$ of the body weight of the birds. Forty two (42) hours post injection, the birds were euthanized, and abdominal macrophage cells were collected for determination of macrophage engulfment percentage.

Delayed type of hypersensitivity reaction (DNCB assay): One percent solution of 2,4 di-nitro-chloro-benzene (DNCB) was prepared in acetone. Five birds from each group at each sampling stage were selected for this assay. One ml of DNCB was dripped drop by drop with an insulin syringe on to the skin of thigh region as a primary inoculation in one inch marked circle. The skin sensitization was done by the method of Tiwary and Goel (1985). The skin thickness before, then after 24 and 72 hours of the DNCB application were measured using a vernier caliper.

Antibody titer against NDV and IBV : Antibody titres for ND and IB virus were measured in the serum samples using mesogenic strain of ND virus and pathogenic variant of IB virus obtained from the Institute of Microbiology. Micro titration haemagglutination inhibition (HI) test was applied for the determination of antibody titer against ND virus. Indirect ELISA test (IDEXX Kit, USA) was performed to evaluate antibody response to IB virus (Boulianne et al., 2013).

Statistical analysis: Data obtained was subjected to two-way analysis of variance and the means were compared by using Duncan's Multiple Range test (Duncan, 1955). A two-way analysis of variance was conducted to compare the data statistically among different groups at various production stages. The data was analyzed by using CoStat $6.4^{\circledR}$ and GraphPad Prism 5.04 ${ }^{\circledR}$ statistical softwares.

\section{RESULTS}

Serum minerals: Serum macro mineral ( $\mathrm{Na}, \mathrm{K}, \mathrm{Ca}, \mathrm{Mg}$ ) concentrations are shown in Table 1 . Overall serum sodium concentration was significantly $(\mathrm{P} \leq 0.05)$ high in vitamin $\mathrm{E}$ and protein supplemented groups. Highest serum potassium concentration was detected in the birds of control group, followed by those of groups fed diets supplemented with vitamin $\mathrm{C}$ and combination diet. The highest serum calcium and magnesium concentrations were observed in the birds fed diet supplemented with vitamin E. Serum micro mineral (Zn, $\mathrm{Fe}, \mathrm{Cu}, \mathrm{Mn}$ ) concentration showed that serum iron, copper and manganese concentrations did not vary among groups. Highest value of zinc was observed in birds fed diet supplemented with vitamin $\mathrm{C}$ and probiotics. These results advocate strengthening of serum mineral profile by vitamins $\mathrm{E}(\mathrm{Na}, \mathrm{Mg}, \mathrm{Ca})$, vitamin $\mathrm{C}(\mathrm{Mg}, \mathrm{Zn})$ and probiotics $(\mathrm{Zn})$ supplementation.

Unopsonized and opsonized macrophage engulfment percentage (60 and 90 min): Statistical analysis of the data showed a high percentage of macrophage engulfment at 60 
Table 1. Mean serum sodium, potassium, calcium, magnesium iron, zinc, copper and mangnese $(\mathrm{mg} / \mathrm{L} \pm \mathrm{SE})$ concentrations of molted control and treated Whit Leghorn breeder males.

\begin{tabular}{|c|c|c|c|c|c|c|c|c|}
\hline & $\begin{array}{c}\text { Sodium } \\
\text { (Na; } \\
\mathrm{mg} / \mathrm{L} \pm \mathrm{SE})\end{array}$ & $\begin{array}{c}\text { Potassium } \\
(\mathrm{K} ; \\
\mathrm{mg} / \mathrm{L} \pm \mathrm{SE})\end{array}$ & $\begin{array}{c}\text { Calcium } \\
(\mathrm{Ca} ; \\
\mathrm{mg} / \mathrm{L} \pm \mathrm{SE})\end{array}$ & $\begin{array}{c}\text { Magnesium } \\
\text { (Mg; } \\
\mathrm{mg} / \mathrm{L} \pm \mathrm{SE})\end{array}$ & $\begin{array}{c}\text { Iron } \\
\text { (Fe; } \\
\mathrm{mg} / \mathrm{L} \pm \mathrm{SE})\end{array}$ & $\begin{array}{c}\text { Zinc } \\
\text { (Zn; } \\
\mathrm{mg} / \mathrm{L} \pm \mathrm{SE})\end{array}$ & $\begin{array}{c}\text { Copper } \\
\text { (Cu; } \\
\mathrm{mg} / \mathrm{L} \pm \mathrm{SE})\end{array}$ & $\begin{array}{c}\text { Mangnese } \\
\text { (Mn; } \\
\mathrm{mg} / \mathrm{L} \pm \mathrm{SE})\end{array}$ \\
\hline \multirow[t]{2}{*}{ Control } & 2341 & 163.79 & 191.9 & 28.22 & 32.70 & 7.360 & 3.33 & 0.97 \\
\hline & $\pm 146.4 \mathrm{~b}$ & $\pm 14.76 \mathrm{a}$ & $\pm 11.35 \mathrm{c}$ & $\pm 1.459 \mathrm{c}$ & \pm 2.613 & $\pm 0.323 \mathrm{e}$ & \pm 0.186 & \pm 0.015 \\
\hline \multirow{2}{*}{ Vitamin C } & 2432 & 156.80 & 212.8 & 33.24 & 32.11 & 11.74 & 3.55 & 1.00 \\
\hline & $\pm 104.4 \mathrm{ab}$ & $\pm 13.69 \mathrm{ab}$ & $\pm 11.96 \mathrm{c}$ & $\pm 1.659 \mathrm{a}$ & \pm 2.488 & $\pm 0.779 \mathrm{a}$ & \pm 0.126 & \pm 0.016 \\
\hline \multirow[t]{2}{*}{ Vitamin E } & 2521 & 147.86 & 248.5 & 34.52 & 32.25 & 11.02 & 3.40 & 0.98 \\
\hline & $\pm 75.30 \mathrm{a}$ & $\pm 12.20 \mathrm{bc}$ & $\pm 11.72 \mathrm{a}$ & $\pm 1.351 \mathrm{a}$ & \pm 1.490 & $\pm 1.050 \mathrm{~b}$ & \pm 0.125 & \pm 0.013 \\
\hline \multirow[t]{2}{*}{ Probiotics } & 2146 & 143.57 & 201.8 & 27.05 & 30.07 & 11.60 & 3.44 & 0.99 \\
\hline & $\pm 141.3 \mathrm{c}$ & $\pm 8.103 \mathrm{c}$ & $\pm 12.73 b c$ & $\pm 0.790 \mathrm{c}$ & \pm 1.279 & $\pm 1.283 \mathrm{a}$ & \pm 0.144 & \pm 0.018 \\
\hline \multirow[t]{2}{*}{$12 \% \mathrm{CP}$} & 2516 & 150.22 & 229.2 & 30.70 & 30.98 & 10.30 & 3.27 & 0.99 \\
\hline & $\pm 84.86 \mathrm{a}$ & $\pm 14.97 \mathrm{bc}$ & $\pm 10.96 \mathrm{ab}$ & $\pm 1.519 \mathrm{~b}$ & \pm 2.013 & $\pm 1.124 \mathrm{c}$ & \pm 0.219 & \pm 0.014 \\
\hline \multirow[t]{2}{*}{ Combination } & 2367 & 156.73 & 225.2 & 28.62 & 32.09 & 9.160 & 3.47 & 0.98 \\
\hline & $\pm 42.99 \mathrm{~b}$ & $\pm 6.787 \mathrm{ab}$ & $\pm 18.40 \mathrm{ab}$ & $\pm 2.027 \mathrm{c}$ & \pm 2.544 & $\pm 1.414 \mathrm{~d}$ & \pm 0.307 & \pm 0.009 \\
\hline
\end{tabular}

${ }^{\text {A-E }}$ Mean values within a column, having different alphabets do differ significantly $(\mathrm{P}<0.05)$.

and 90 minutes under unopsonized (not sensitized with antibody) condition, in vitamin E supplemented group followed by vitamin $\mathrm{C}$ and combination groups. Similarly, macrophage engulfment percentage at 60 and 90 minutes under opsonized (sensitized with antibody) condition, was high in birds supplemented with vitamin E, followed by birds of vitamin C supplemented group (Table 2).

Table 2. Mean macrophage engulfment percentage $(\% \pm \mathrm{SE})$ at $60 \& 90$ minutes in opsonized \& unopsonized condition of molted control and treated White Leghorn breeder males.

\begin{tabular}{lcccc}
\hline & \multicolumn{2}{c}{ Unopsonized } & \multicolumn{2}{c}{ Opsonized } \\
\cline { 2 - 5 } & 60 min. & $\mathbf{9 0}$ min. & $\mathbf{6 0}$ min. & 90 min. \\
& $(\%)$ & $(\%)$ & $(\%)$ & $(\%)$ \\
\hline Control & 10.77 & 11.66 & 42.16 & 52.92 \\
& $\pm 0.192 \mathrm{~d}$ & $\pm 0.720 \mathrm{~d}$ & $\pm 1.170 \mathrm{~d}$ & $\pm 0.782 \mathrm{e}$ \\
Vitamin C & 13.06 & 14.67 & 48.61 & 60.73 \\
& $\pm 0.514 \mathrm{~b}$ & $\pm 0.652 \mathrm{~b}$ & $\pm 1.468 \mathrm{~b}$ & $\pm 1.003 \mathrm{~b}$ \\
Vitamin E & 15.52 & 16.59 & 52.76 & 71.53 \\
& $\pm 0.797 \mathrm{a}$ & $\pm 0.858 \mathrm{a}$ & $\pm 0.532 \mathrm{a}$ & $\pm 3.303 \mathrm{a}$ \\
Probiotics & 11.61 & 13.57 & 45.96 & 56.99 \\
& $\pm 0.253 \mathrm{c}$ & $\pm 0.724 \mathrm{c}$ & $\pm 1.326 \mathrm{c}$ & $\pm 1.033 \mathrm{~d}$ \\
12\% CP & 11.87 & 13.46 & 45.67 & 56.21 \\
& $\pm 0.371 \mathrm{c}$ & $\pm 0.758 \mathrm{c}$ & $\pm 0.384 \mathrm{c}$ & $\pm 1.319 \mathrm{~d}$ \\
Combination & 12.77 & 14.87 & 45.28 & 59.12 \\
& $\pm 0.725 \mathrm{~b}$ & $\pm 0.425 \mathrm{~b}$ & $\pm 0.268 \mathrm{c}$ & $\pm 1.591 \mathrm{c}$ \\
\hline
\end{tabular}

${ }^{\mathrm{A}-\mathrm{E}}$ Mean values within a column, having different alphabets do differ significantly $(\mathrm{P}<0.05)$.

DNCB assay: Results of delayed type of hypersensitivity, after 24 and 72 hours of DNCB application showed significantly higher $(\mathrm{P} \leq 0.05)$ values of skin thickness in birds of vitamin E supplemented group when compared to control, followed by vitamin $\mathrm{C}$ and probiotics group (Table 3 ).
Table 3. Overall mean, increase in skin thickness $(\mathrm{mm} \pm$ SE) of molted control and treated White Leghorn breeder males groups at $24 \& 72 \mathrm{hrs}$ after the inoculation of DNCB.

\begin{tabular}{lcc}
\hline & $\mathbf{2 4} \mathbf{~ h r s}$ & $\mathbf{7 2 ~ h r s}$ \\
\hline Control & $0.93 \pm 0.018 \mathrm{~d}$ & $1.01 \pm 0.058 \mathrm{~d}$ \\
Vitamin C & $2.10 \pm 0.117 \mathrm{~b}$ & $1.80 \pm 0.040 \mathrm{~b}$ \\
Vitamin E & $3.05 \pm 0.332 \mathrm{a}$ & $3.14 \pm 0.206 \mathrm{a}$ \\
Probiotics & $2.16 \pm 0.068 \mathrm{~b}$ & $1.73 \pm 0.104 \mathrm{~b}$ \\
$12 \%$ CP & $1.18 \pm 0.067 \mathrm{c}$ & $1.81 \pm 0.020 \mathrm{~b}$ \\
Combination & $1.29 \pm 0.032 \mathrm{c}$ & $1.28 \pm 0.016 \mathrm{c}$ \\
\hline
\end{tabular}

A-D Mean values within a column, having different alphabets do differ significantly $(\mathrm{P}<0.05)$.

Serum antibody titer against ND and IB: The results of geometric mean titer for ND and IB virus (Table 4) showed that in vitamin E supplemented group, GMT for ND virus was highest followed by vitamin $\mathrm{C}$ and probiotics supplemented groups. Similarly, GMT for IB virus was also highest in vitamin $\mathrm{E}$ supplemented group followed by probiotics and vitamin $\mathrm{C}$ supplemented groups.

Table 4. Serum geometric mean antibody titer (GMT) of molted control and treated White Leghorn breeder males against ND (New Castle Disease) \& IB (Infectious Bronchitis) at different weeks of semen production.

\begin{tabular}{lcc}
\hline & ND (GMT) & IB (GMT) \\
\hline Control & 168 & 5338.52 \\
Vitamin C & 337 & 5931.60 \\
Vitamin E & 445 & 7698.72 \\
Probiotics & 256 & 6219.72 \\
$12 \%$ CP & 168 & 5825.54 \\
Combination & 222 & 5253.16 \\
\hline
\end{tabular}




\section{DISCUSSION}

Avian immune system has two types; humoral and cell mediated immunity, which provides protection and prevention against pathogens. Cell mediated immunity destroys the cells which are infected with foreign agents like bacteria (Aderem et al., 2014). During this process, macrophage engulfs foreign particles and thus provides immunity to poultry birds. The results showed that birds fed diet supplemented with vitamin E exhibited the highest percentage of macrophage engulfment of sheep RBCs in opsonised and unopsonised (at 60 and 90 minutes) conditions. Meydani et al. (1990) have reviewed that membrane phospholipids of macrophages contain high concentration of arachidonic acid. Which upon stimulation release up to $50 \%$ arachidonic acid to form reactive oxygen species (ROS) like: prostaglandin, hydroxeicosatetraenoic acid and leukotriene. Being an antioxidant, vitamin $\mathrm{E}$ has been observed to decrease production of ROS in immune cells and enhance cell mediated immunity (macrophage engulfment). This highest percentage of macrophage engulfment is compatible with those observed by Gore and Qureshi (1997) who found that addition of $10 \mathrm{IU}$ of vitamin E markedly increased the percentage of macrophage engulfment in chickens, when those were injected (in ovo) during embryonic stage of life. Increase in macrophage engulfment percentage has also been observed by Niu et al. (2009) due to dietary addition of vitamin E (200 mg/Kg diet) in stressed broilers. As suggested by Qureshi et al. (2000) the process of macrophage engulfment is a membrane mediated phenomenon and can be sustained by making available high levels of vitamin $\mathrm{E}$ required for the process of phagocytosis. Increased macrophage engulfment response in molted White Leghorn breeder males, may also be related to the decrease in cortisol level in the birds fed diet containing vitamin $\mathrm{E}$ when compared to those of control group, as has been observed by Anwar and Rahman (2011) in layers, probably due to the production of nitric oxide. Chicken macrophages have been known to produce nitric oxide (Hussain and Qureshi, 1997) under various immunological stimuli.

Higher dose of vitamin E maintains integrity of macrophage membrane, which is important for phagocytosis, being antioxidant it prevents the oxidation of the arachidonic acid, important for biosynthesis pathway of prostaglandin having immunosuppressive role at an increased level. A significant increase in mean nitric oxide has been observed by supplementation of vitamin $\mathrm{E}$ in the diet of male broiler breeders (Khan et al., 2012). Immune-modulation potential has been validated in a study through utilization of dietary vit. E (Sandhu et al., 2013). The immunomodulatory role of vitamin $\mathrm{E}$ has been found to be linked with its antioxidant potential (Khan et al., 2012). Role of vitamin E may be immuonomodulatory itself or its immunomodulatory effect may correspond to the level which is required for lipid peroxidation inhibition and protection of microsomes and mitochondria of liver from oxidative stress (Leshchinsky and Klasing, 2001). Being primary antioxidant of cell membrane, it is for the prevention of fatty acid peroxidation. Both in vitro and in vivo investigation showed that vitamin $\mathrm{E}$ inhibits peroxidation of lipid by breaking chain propagation (Niki, 2014).

Response regarding skin thickness of the birds was found to be more stable both after 24 and 72 hours of DNCB sensitization, depicting a significantly higher immune potentiating role of all the treatments. However, the effect due to the dietary inclusion of vitamin $\mathrm{E}$ was more pronounced as compared to all other treatment groups. The effect due to probiotics supplementation after 24 hours was also higher when compared to its counter parts but was still lower than vitamin E group. The delayed skin inflammation resolution may be attributed to body's strengthened immune responses. Dietary supplementation of probiotics is known to have a significant immuno-stimulatory role in molted poultry birds (Anwar et al., 2015). Probiotics are powerful strategy for manipulation of host immune response and microbial composition. Direct interaction between gut microbiota and immune system has been reviewed that allows host to tolerate various antigens present in gut (Vieira et al., 2013). Growing number of studies showed beneficial effects of probiotics on host health (Mountzouris et al., 2010). A marked increase in cutaneous basophilic hypersensitivity response $(\mathrm{CBH})$ in skin thickness of 64 weeks old White Leghorn layers after inoculating with phyto-haemagglutinin-P (PHP) has also been observed by Panda et al. (2003) due to the dietary addition of probiotics. They also reported that increased migration and accumulation of T-cells at the site of inoculation of DNCB was responsible for the increased hypersensitivity response of skin in the birds fed probiotics supplemented diets.

Serum antibody titers against ND and IB vaccine, in molted White Leghorn breeder males were found to be higher for all the treatments. In case of IB, the effect due to the dietary inclusion of vitamin E $(\mathrm{GMT}=7698.72)$ was more pronounced followed by probiotics $(\mathrm{GMT}=6219.72)$ and vitamin C (GMT=5931.6) supplemented groups. While serum antibody titers against ND vaccine were more pronounced vitamin E $(\mathrm{GMT}=445)$ followed by vitamin $\mathrm{C}(\mathrm{GMT}=337)$ and probiotics $(\mathrm{GMT}=256)$ treated groups. Against ND, immunopotentiating effect is produced by $\mathrm{Zn}$ induced molting (Sandhu et al., 2007). Similar to our findings, ascorbic acid supplementation @ 800mg/Kg increased antibody titer in heat stressed broilers, against ND vaccine (Aengwanich et al., 2003). Similarly, birds supplemented with vitamin E used @ $20 \mathrm{mg} / \mathrm{Kg}$ increased antibody titers against IB vaccine in cockerels (Lin, 2005). Dose dependant increase in production of antibody was found by Leshchinsky and Klasing (2001) in response to attenuated IB virus between 0 and $25 \mathrm{IU} / \mathrm{Kg}$ of supplementation of vitamin $\mathrm{E}$. 
Conclusion: Vitamin $\mathrm{E}$ and vitamin $\mathrm{C}$ are useful in improving immunity (cell mediated and humoral), and strengthening of serum mineral profile during post molt period, in White Leghorn breeder males. Probiotics supplementation also have role in improving immune status of molted birds. However, vitamin $\mathrm{E}$ is found to be the best option for improving health and immune response against Newcastle and infectious bronchitis disease. Hence dietary supplementation of vitamin $\mathrm{E}$ is recommended in molted birds.

Acknowledgment: This research work was conducted under Research Project PSF/NSLP/P-AU (245). Authors are highly thankful to Pakistan Science Foundation (PSF) for the financial support.

\section{REFERANCES}

Aderem, A., F. Hayashi, K.D. Smith, D.M. Underhill and A. Ozinsky. 2014. "Toll like receptor 5 ligands and methods of use". U.S. Patent 8,703,146.

Aengwanich, W., P. Sridama, Y. Phasuk, T. Vongpralab, P. Pakdee, S. Katawatin and S. Simaraks. 2003. Effects of ascorbic acid on cell mediated, humoral immune response and pathophysiology of white blood cells in broilers under heat stress. Cell 25: 298.

Akbari, M.R., H. Kermanshahi, H.N. Moghaddam, A.R.H. Moussavi and J.T. Afshari. 2008. Effect of wheat-soy soybean meal based diet supplementation with vitamin $\mathrm{A}$, vitamin $\mathrm{E}$ and zinc on blood cells, organ weights and humoral immune response in broiler chickens. J. Anim. Vet. Adv. 7: 297-304.

Anwar, H. and Z.U. Rahman. 2011. The dynamics of trace elements $(\mathrm{Cu}, \mathrm{Zn}, \mathrm{Mn}$ and $\mathrm{Fe})$ metabolism in the molted layers supplemented with protein, symbiotic and probiotics. Poult. Sci. 90: 135.

Anwar, H., Z.U. Rahman, I. Javed and F. Muhammad. 2015. Immune potentiating role of protein, probiotics and symbiotic supplementation in moulted White Leghorn hens. Avi. Bio. Res. 8: 25-34.

Boulianne M, M.L. Brash, B.R. Charlton, S.H. Fitz-Coy, R.M. Fulton, R.J. Julian, M.W. Jackwood, D. Ojkic, L.J. Newman, J.E. Sander, H.L. Shivaprasad, E. WallnerPendleton and P.R. Woolcock. 2013. Avian Disease Manual, $7^{\text {th }}$ Ed. American Association of Avian Pathologists.

Duncan, D.B. 1955. Multiple range and multiple F-test. Biometrics 11: 1-42.

Gore, A.B. and M.A. Qureshi. 1997. Enhancement of humoral and cellular immunity by vitamin $\mathrm{E}$ after embryonic exposure. Poult. Sci. 76:984-991.

Hussain, I. and M.A. Qureshi. 1997. Nitricoxide synthase and mRNA expression in chicken macrophages. Poult. Sci. 76: 1524-1530.
Iftikhar, A., T. Khaliq, J.A. Khan, H. Anwar, I. Javed, H. Muzaffar and A. Mahmood. 2015. Efficacy of Vitamins, Probiotics and Protein Supplementation on Serum Health Biomarkers of Molted Male Layer Breeders. Pak. Vet. J. 35:519-521.

Khan, R.U., Z. Nikousefat, M. Javdani, V. Tufarelli and V. Laudadio. 2011. Zinc-induced moulting: production and physiology. World's Poult. Sci. J. 67: 497-506.

Khan, R.U., Z.U. Rahman, I. Javed and F. Muhammad. 2013. Effect of vitamins, probiotics and protein level on semen traits and seminal plasma biochemical parameters of post- moult male broiler breeders. Br. Poult. Sci. 54: 120129.

Khan, R.U., Z.U. Rahman, I. Javed and F. Muhammad. 2014. Serum antioxidants and trace minerals as influenced by vitamins, probiotics and proteins in broiler breeders. J. Appl. Anim. Res. 42: 249-255.

Khan, R.U., Z.U. Rahman, Z. Nikousefat, M. Javdani, V. Tufarelli, C. Dario, M. Selvaggi and V. Laudadio. 2012. Immunomodulating effects of vitamin $\mathrm{E}$ in broilers. World's Poult. Sci. J. 68:31-40.

Leshchinsky, T.V. and K.C. Klasing. 2001. Relationship between the level of dietary vitamin $\mathrm{E}$ and the immune response of broiler chickens. Poult. Sci. 80: 1590-1599.

Li, Y.B., Q.Q. Xu, C.J. Yang, X. Yang, L. Lv, C.H. Yin, X.L. Liu and H. Yan. 2014. Effects of probiotics on the growth performance and intestinal micro flora of broiler chickens. Pak. J. Pharm. Sci. 27: 713-717.

Lin, Y.F., S.J. Chang, J.R. Yang, Y.P. Lee and A.L. Hsu. 2005. Effects of supplemental vitamin $\mathrm{E}$ during the mature period on the reproduction performance of Taiwan native chicken cockerels. Br. Poult. Sci. 46: 366373.

Mountzouris, K.C., P. Tsitrsikos, I. Palamidi, A. Arvaniti, M. Mohnl, G. Schatzmayr and K. Fegeros. 2010. Effects of probiotic inclusion levels in broiler nutrition on growth performance, nutrient digestibility,s plasma immunoglobulins, and cecal microflora composition. Poult. Sci. 89: 58-67.

Meydani, S.N., M.P. Barklund, S. Liu, M. Meydani, R.A. Miller, J.G. Cannon, F.D. Morrow, and J.B. Blumberg. 1990. Vitamin E supplementation enhances cellmediated immunity in healthy elderly subjects. Am. J. Clin. Nutr. 52:557-563.

Niki, E. 2014. Role of vitamin E as a lipid-soluble peroxyl radical scavenger: in vitro and in vivo evidence. Free Radic. Biol. Med. 66: 3-12.

Niu, Z.Y., F.Z. Liu, Q.L. Yan and W.C. Li. 2009. Effects of different levels of vitamin $\mathrm{E}$ on growth performance and immune responses of broilers under heat stress. Poult. Sci. 88: 2101-2107.

Panda, A.K., M.R. Reddy, S.V. Rama Rao and N.K. Praharaj. 2003. Production performance, serum/ yolk cholesterol and immune competence of white leg horn layers as 
influenced by dietary supplementation with probiotic. Trop. Anim. Health Prod. 35: 85-94.

Qureshi, M.A., C.L. Heggen and I. Hussain. 2000. Avian macrophage: Effector functions in health and disease. Dev. Comp. Immunol. 24: 103-119.

Qureshi, M.A., R.R. Dietert and L.D. Bacon. 1986. Genetic variation in the recruitment and activation of chicken peritoneal macrophages. Exp. Biol. Med. 181: 560-568.

Rahman, Z.U. and M.S. Akhtar. 1993. Trace elements concentration in liver, kidney and serum of healthy domestic animals. Proceedings of International Synopsia on Trace Elements and Liver Diseases, pp.199-205.

Sahin, K., N. Sahin, M. Onderci, S. Yaralioglu and O. Kucuk. 2001. Protective role of supplemental vitamin E on lipid peroxidation, vitamins $\mathrm{E}, \mathrm{A}$ and some mineral concentrations of broilers reared under heat stress. Vet. Med. Czech. 46: 140-144.

Sandhu, M.A., M. Raza, F. Afzal, F. Ahmad and M.S. Anjum. 2013. Managing immunocompetence of broiler chicken through vitamin $\mathrm{E}$ supplementation at low ambient temperature. Int. J. Agri. Biol. 15: 1051-1058.
Sandhu, M.A., Z.U. Rahman and S.U. Rahman. 2006. Dynamics of macrophages in laying hens during second and third production cycles after zinc induced molting. J. Poult. Sci. 43: 286-295.

Sandhu, M.A., Z.U. Rahman and S.U. Rahman. 2007. Effects of induced molting on some immunological parameters in laying hens (Gallus domesticus). Arch. Geflugelk. $71: 110$

Tiwary, B.K. and M.C. Goel. 1985. Contact sensitivity to DNCB in normal and cell mediatedimmunity deficient chickens: in vivo detection and correlation with lymphocyte transformation and graft-versus-host reaction. Vet. Immunol. Immunopathol. 8: 329-39.

Vieira, A.T., M.M. Teixeira and F. S. Martins. 2013. The role of probiotics and prebiotics in inducing gut immunity. Front. Immunol. 4:445.

Wu, C.C., T. Dorairajan and T.L. Lin. 2000. Effect of ascorbic acid supplementation on the immune response of chickens vaccinated and challenged with infectious bursal disease virus. Vet. Immun. Immunopath. 74: 145152. 